Volume 3 Issue 1 (2019) Pages 78 - 87

Jurnal Obsesi : Jurnal Pendidikan Anak Usia Dini

DOI: $10.31004 /$ obsesi.v3i1.148

\title{
The Impact of Academic Press and Student Teacher Relationship on Children's Emotional Adjustment
}

\author{
Fadilla Ayuningtyas ${ }^{1 凶}$, Sofia Hartati ${ }^{2}$, Tjipto Sumadi ${ }^{3}$ \\ Pascasarjana Pendidikan Anak Usia Dini Universitas Negeri Jakarta
}

\begin{abstract}
The purpose of this study is to examine the impact of the academic press and student teacher relations on emotional adjustment in children aged 7-8 years. This study used a survey method with 132 respondents in East Jakarta, selected using stratified multistage cluster random sampling. Data collection uses three research instruments in the form of scales 1-3 which is adapted and developed from research indicators using student academic survey press with reliability values $(\alpha=.465)$, short version Student Teacher Relationship Scale $(\alpha=.599)$, and School Liking and Avoidance Questionnaire $(\alpha=.715)$. The results showed that 1) academic press did not had a direct negative effect on emotional adjustment, 2) teacher-student relations had a direct positive effect on emotional adjustment, and 3) academic press and teacher relations simultaneously had a positive effect on emotional adjustment which explained indirect effect of the academic press on emotional adjustment through student teacher relations as a mediator. This indirect influence illustrates that in a state of high positive relations, the academic press's role that the teacher seeks is understood by students as a way for teachers to improve achievement and emotional adjustment. In addition, the positive effect was increasing greater when academic press related together with the teacher-student relationship compared to the partial effect of student relations on emotional adjustment. This greater effect requires a ranking of the partial correlation of the teacher-student relation which is above or greater than the ranking of the partial academic press only.
\end{abstract}

Keyword: academic press, emotional adjustment, student-teacher relationship, academic achievement.

\begin{abstract}
Abstrak
Penelitian ini bertujuan menguji pengaruh academic press dan relasi guru siswa terhadap emotional adjustment pada anak usia 7-8 tahun. Penelitian ini menggunakan metode survei dengan jumlah responden 132 anak di Jakarta Timur yang dipilih menggunakan stratified multistage cluster random sampling. Pengumpulan data menggunakan tiga instrumen penelitian berbentuk skala 1-3 yang diadaptasi dan dikembangkan dari indikator penelitian yang menggunakan student survey academic press dengan nilai reliabilitas ( $\alpha=.465)$, Student Teacher Relationship Scale versi pendek $(\alpha=.599)$, dan School Liking and Avoidance Questionnaire $(\alpha=.715)$. Hasil penelitian menunjukkan bahwa 1) academic press tidak berpengaruh negatif secara langsung terhadap emotional adjustment, 2) relasi gurusiswa berpengaruh positif terhadap emotional adjustment, serta 3) academic press dan relasi guru-siswa secara simultan berpengaruh positif terhadap emotional adjustment yang dijelaskan bahwa ada pengaruh tidak langsung academic press terhadap emotional adjustment melalui relasi guru siswa. Pengaruh tidak langsung ini menggambarkan dalam keadaan relasi positif yang tinggi, peran academic press yang diupayakan guru diterima siswa sebagai cara guru meningkatkan prestasi dan kesejahteraan emosi. Pengaruh positif ini mensyaratkan peringkat korelasi parsial relasi guru-siswa lebih tinggi dari peringkat korelasi parsial academic press.
\end{abstract}

Kata Kunci: academic press, emotional adjustment, relasi guru siswa, prestasi akademik.

@ Jurnal Obsesi Prodi PG-PAUD FIP UPTT 2019

$\triangle$ Corresponding author :

Address : Jl. Porselen Raya No.19, Jakarta Timur

Email : fadillaayuningtyas@gmail.com

Phone : $(+62) 813934366$

ISSN 2356-1327 (Media Cetak)

ISSN 2549-8959 (Media Online) 


\section{PENDAHULUAN}

Pandangan dunia mengenai pendidikan telah berubah. Sebelumnya, Millennium Development Goals yang berfokus meningkatkan akses pendidikan dasar bagi masyarakat, dilaporkan mampu meningkatkan $83 \%$ pendaftar pendidikan dasar dan menurunkan 57 juta siswa putus sekolah di usia Sekolah Dasar (United Nations, 2015). Setelah MDGs berakhir, tujuan pendidikan seluruh dunia dalam Sustainable Development Goals dipriortaskan pada penguasaan pengetahuan dan keterampilan yang mempromosikan pembangunan berkelanjutan lewat hal-hal yang berkaitan dengan pendidikan (UNESCO, 2016). Tujuan ini memberikan gambaran, saat ini dunia menyadari bahwa potensi kesejahteraan dan penciptaan peradaban manusia yang lebih baik dapat didukung dengan peningkatan kualitas pendidikan.

Kualitas pendidikan juga sedang menjadi perhatian pemerintah Indonesia. Saat ini, implementasi sistem zonasi dalam penerimaan siswa baru ditujukan untuk memeratakan kualitas pendidikan di Indonesia (Kemendikbud, 2017) agar tidak ada lagi favoritisme disebagian sekolah oleh masyarakat. Pada prinsipnya, kualitas pendidikan tidak semata diukur dengan kesuksesan akademik sisi kognitif, melainkan juga seimbang dengan sisi sosial emosinya. Oleh karena itu, pada tataran penyelenggaraan, kurangnya perhatian pada sisi sosial emosi siswa mengakibatkan pincangnya proses pendidikan dilembaga sekolah.

Para peneliti menyebut ada perubahan besar yang terjadi pada Taman Kanak-kanak di dunia dalam kurun waktu seabad. Perubahan tersebut ditandai dengan kelas yang menjalankan intruksi akademis lebih serius dan mempercepat pengajaran akademis formal pada anak-anak (Russell, 2011). Pendidikan anak usia dini telah menghilangkan banyak kesempatan untuk bermain dan menggantinya dengan kegiatan pembelajaran terstruktur (Nicolopoulou, 2010), serta meningkatnya penekanan pada prestasi akademik membuat waktu bermain anak diisi dengan aktivitas mengerjakan lembar kerja, latihan matematika, dan mengisi tes-tes berstandar (Hemphill, 2006). Upaya peningkatan prestasi akademik semacam ini dikenal dengan istilah academic press.

Istilah academic press disebut sebagai upaya sekolah dalam menciptakan iklim akademik yang berfokus pada pencapaian prestasi terbaik dari para siswanya (Lee et al., 1999). Hal ini yang membedakannya dengan academic stress. Academic press sebagai upaya dari lingkungan eksternal siswa yang menekankan pencapaian prestasi akademik tinggi melalui upaya pengajaran dan pembelajaran, sedangkan academic stress merupakan istilah psikologis yang termanifestasi dalam keadaan diri anak yang tertekan, seperti khawatir dan depresi yang disadari sebagai permasalahan (Prabu, 2015). Namun bagi masyarakat, academic press dipandang sebagai tekanan yang bersifat negatif bukan sebagai upaya normatif sekolah yang bertujuan pada terciptanya academic success.

Academic success adalah tujuan utama berbagai kebijakan sekolah efektif yang menerapkan academic press dalam iklim belajarnya, yang disisi lain juga mengusahakan pembangunan iklim sosialemosional lewat hubungan yang hangat antara siswa dengan teman sebaya dan orang dewasa disekolah. Pianta (2001) menyebut relasi anak dengan orang dewasa berperan penting dalam pengembangan kompetensi akademik, sosial dan emosional anak selama mengikuti proses pendidikan disemua jenjang. Salah satu orang dewasa yang banyak melakukan interaksi dengan anak adalah guru.

Keberadaan guru di sekolah memiliki pengaruh yang besar bagi siswa, apalagi bagi yang berada dalam rentang usia 0-8 tahun atau periode usia dini (UNESCO, 2015). Guru berperan penting sebagai model yang istimewa dalam pandangan siswa. Namun, konflik dengan guru tidak dapat dielakkan dalam interaksi di sekolah yang mengakibatkan timbulnya rasa tidak aman dan ketidaksukaan terhadap sekolah. 
Sebagai contoh, pada awal tahun 2018, seorang siswa dihukum oleh gurunya dengan menjilati WC (water closet) karena tidak membawa tugas sekolah (Damanik, 2018). Konflik dengan guru semacam ini menjadi penyebab siswa trauma dengan sekolah (Garmabrata, 2018).

Meskipun tidak merepresentasikan usia anak usia dini (0-8 tahun), data Ikhtisar Eksekutif Srategi Nasional Penghapusan Kekerasan Terhadap Anak 2016-2020 yang dibuat Kementerian Pemberdayaan Perempuan dan Perlindungan Anak menyebut sebanyak $84 \%$ siswa pernah mengalami kekerasan atau konflik di sekolah dan sebagian diantaranya $(45 \%)$ siswa laki-laki mengatakan bahwa pihak lain yang terlibat dalam kekerasan atau konflik tersebut adalah guru atau petugas sekolah lain (Nadlir, 2018). Hal ini berelasi dengan banyaknya pengaduan yang diterima Komisi Perlindungan Anak Indonesia terkait konflik yang melibatkan siswa dan guru di sekolahan, yang menciptakan persepsi bahwa sekolah seringkali menjadi tempat yang tidak aman bagi siswa (Awaliyah, 2018). Fakta-fakta ini menjadi alasan bahwa masih banyak permasalahan pendidikan yang terjadi pada lingkup sekolah. Keberadaan academic press dan konflik pada relasi-guru siswa diduga memiliki hubungan sekaligus berpengaruh pada emotional adjustment siswa terhadap sekolah.

Penelitian sebelumnya menyebut emotional adjustment sebagai perasaan terhadap sekolah semisal menghargai dan merasa memiliki sekolah (school belonging) dan sejauh mana penghargaannya pada keberhasilan akademis (Smith, 2011). Emotional adjustment berperan penting dalam memprediksi keterlibatan anak dalam sekolah, karena emotional adjustment diketahui sebagai ukuran keinginan anak menghadiri ataupun mengabaikan dan menghindari sekolah (Ladd, Buhs and Seid, 2000; Honma and Uchiyama, 2014).

Emotional adjustment juga berpengaruh pada keadaan emosi, perilaku, dan performa belajar siswa (Valiente,
Lemery-Chalfant and Castro, 2007), berkorelasi dengan konsep diri yang positif terhadap performa akdemik dan pengajaran sejumlah mata pelajaran (Ireson and Hallam, 2005), berkorelasi dengan roletaking ability (Honma and Uchiyama, 2016) dan memoderatori presepsi tentang keamanan sekolah pada perkembangan kepercayaan diri siswa (Zhang et al., 2016). Hal ini memperlihatkan bahwa emotional adjustment dapat berkaitan dengan berbagai faktor yang melibatkan siswa dalam interaksi atau pengalamannya di sekolah (Murray, Murray and Waas, 2008).

Adapun relasi guru siswa disebut sebagai presepsi atas rasa hangat, kepercayaan, komunikasi yang terbuka serta konflik dalam sebuah hubungan (Murray, Murray and Waas, 2008). Pianta (Pianta, 2001) merinci ada tiga dimensi didalamnya yaitu kedekatan, konflik, dan kebergantungan. Oleh karena itu, ada dua kelompok sifat relasi yang diidentifikasi peneliti yakni relasi yang bersifat positif, dan bersifat negatif. Relasi bersifat positif dijelaskan sebagai relasi yang diwarnai dengan kehangatan dan komunikasi terbuka antara guru dan siswa, sebaliknya relasi penuh konflik (negatif) diwarnai dengan tingginya ketegangan, permusuhan, dan perselisihan serta adanya tingkat kebergantungan tinggi dari siswa.

Secara bersamaan, relasi positif memprediksikan hal-hal yang terkait dengan hasil positif (positif outcomes) siswa di sekolah begitu pula relasi bersifat penuh konflik memprediksi hasil yang negatif pula (Hamre and Pianta, 2001; Hamre et al., 2008; Arbeau, Coplan and Weeks, 2010; Roorda et al., 2011). Sebagai contoh, relasi yang positif membuat siswa merasa aman dilingkungan sekolah, meningkatnya efikasi diri akademiknya, membuat hubungan yang positif dengan teman sebaya, dan mendapatkan keuntungan akademis yang lebih besar dibandingkan siswa yang berelasi penuh konflik (Hamre and Pianta, 2006). Persepsi inilah yang menjadi landasan dugaan bahwa ada hubungan yang kuat antara relasi guru- 
siswa dengan sejumlah kompetensi sosial dan penyesuaian diri siswa di sekolah.

Sedangkan academic press didefinisikan sebagai pendekatan dalam pengaturan sekolah dalam rangka peningkatan prestasi akademik yang meliputi penambahan waktu untuk pengajaran, pekerjaan rumah yang lebih banyak, target capaian prestasi yang spesifik, dan harapan berprestasi tinggi (Deasyanti, 2015). Survei academic press biasanya dilakukan pada siswa untuk menggali persepsi anak pada berbagai hal seperti tuntutan memiliki performa belajar yang tinggi, menyelesaikan PR setiap malam, mendapat hasil terbaik setiap saat, dan dorongan melakukan tambahan tugas apabila tidak memahami konten yang diajarkan (Lee et al., 1999).

Academic press diidentifikasi memiliki hubungan signifikan pada prestasi akademik. Shouse (1996) menemukan hubungan paling kuat terjadi pada siswa dengan status sosial-ekonomi (SES) rendah, sedangkan hubungan sosial yang kuat dengan komunitas memiliki dampak negatif pada prestasi belajar pada siswa dengan SES dan academic press rendah, serta pada siswa dengan SES rendah-menengah, prestasi terbaik berasal dari kombinasi kuat antara academic press dengan hubungan sosial dalam komunitas. Penelitian Shouse yang menyatakan adanya vareasi hubungan signifikan academic press dengan prestasi akademik ini menjadi salah satu dasar pendugaan bahwa pada anak usia dini academic press memiliki pengaruh negatif sedangkan relasi guru-siswa berpengaruh positif terhadap emotional adjustment anak.

Sedikitnya penelitian di Indonesia khususnya pada anak usia dini yang dapat dirujuk untuk menjelaskan hubungan ketiga variabel ini membuat penelitian ini dirasa penting dilakukan. Penelitian ini bertujuan menjawab bagaimana pengaruh academic press dan relasi guru siswa terhadap emotional adjustment baik secara parsial maupun simultan. Jawaban dari penelitian ini diharapakan menjadi masukan penting dalam pembangunan konsep pendidikan anak usia dini dan masa peralihannya menuju pendidikan formal yang seringkali memiliki perbedaan pandangan ditataran praktis, khususnya pada perhatian dimensi emosi dan sosial anak serta tantangan prestasi akademik. Selain itu, sebagai promosi pada isu psikologi positif yang menginginkan peningkatan pemahaman praktisi pendidikan pada quality of school life yang juga menjadi fokus pembangunan berkelanjutan.

\section{METODE}

Penelitian ini menggunakan metode survei dengan jumlah responden 132 anak usia 7-8 tahun di Jakarta Timur. Populasi penelitian ini adalah anak-anak yang bersekolah di institusi terakreditasi A di Jakarta Timur, sedangkan pemilihan sampel menggunakan stratified multistage cluster random sampling.

Survei dilakukan dengan membacakan butir-butir pertanyaan kuisioner berbentuk skala dengan skor jawaban 1-3 pada responden. Instrumen survei yang digunakan diadaptasi dari School Liking and Advoidance Questionnaire (Smith, 2011) dengan nilai Chronnbach's Alpha 0,715 untuk mengukur emotional adjustment. Selain itu instrumen academic press dikembangkan menggunakan indikator-indikator yang digunakan Lee at al (Lee et al., 1999) dan Shouse (Shouse, 1996) dengan reliabilitas 0,465 , serta instrumen untuk mengukur kedekatan relasi guru-siswa diadaptasi dari Teacher-Student Relationship Scale Short Version (Pianta, 2001) dengan niali reliabilitas 0,599 .

\section{HASIL DAN PEMBAHASAN}

Peneliti menemukan tidak terdapat pengaruh negatif secara langsung academic press terhadap emotional adjustment namun menemukan pengaruh positif secara langsung pada emotional adjustmnet atas relasi guru-siswa serta secara bersama (simultan) academic press dan relasi gurusiswa berpengaruh positif terhadap emotional adjustmnet yang kemudian hasil ketiga ini mengarah pada temuan baru bahwa pengaruh yang diberikan oleh 
academic press berupa pengaruh tidak langsung.

Analisis statistik menunjukkan beberapa hasil, diantaranya tidak ada pengaruh negatif academic press terhadap emotional adjustment dimana $t_{h}(-1,101)<$ $t_{t}(-1,645)$ diuji pada sisi kiri kurva didaerah penolakan $\mathrm{H}_{0}$. Selain itu pengujian juga menyimpulkan bahwa ada pengaruh positif secara langsung relasi guru-siswa terhadap emotional adjustment $\left(\mathrm{t}_{\mathrm{h}}=3,044<\right.$ $\left.1,645=\mathrm{t}_{\mathrm{t}}\right)$.

Selanjutnya, koefisien korelasi parsial academic press atas emotional adjustment dengan mengontrol relasi guru-siswa tidak signifikan atau tidak bernilai. Sedangkan korelasi parsial $\mathrm{r}_{\mathrm{y} 2.1}$ dianggap bermakna, atau koefisien korelasi relasi guru-siswa dan emotional adjustment dengan mengontrol academic press adalah signifikan.

Selanjutnya diketahui koefisien korelasi simultan bernilai signifikan atau terdapat pengaruh secara bersama-sama academic press dan relasi guru siswa terhadap emotional adjustment dengan nilai pengaruh yang ditunjukkan oleh $\mathrm{R}$ square sebesar 0,083 atau 8,3\%. Hal ini bermakna sebanyak $8,3 \%$ variabilitas emotional adjustment dapat dijelaskan oleh academic press dan relasi guru-siswa. Namun, seperti yang ditunjukkan pada pembuktian hipotesis pertama, tidak terdapat hubungan negatif secara langsung academic press atas emotional adjustment. Kemudian dengan mempertimbangkan hasil analisis R Square $(0,83)$ yang meningkat ketika academic press dan relasi guru-siswa dikorelasikan bersamaan dibanding ketika relasi gurusiswa berkorelasi secara parsial dengan emotional adjustment (0,75), maka diasumsikan ada pengaruh tidak langsung yang disumbangkan oleh academic press melalui relasi guru-siswa.

Pengaruh tidak langsung dari academic press terhadap emotional adjustment berdasarkan data empiris didukung dengan analisis ststistik yang memperlihatkan adanya korelasi academic press atas relasi guru siswa. Setelah pengujian dilakukan, diketahui pengaruh langsung academic press terhadap relasi guru-siswa bersifat negatif $(-0,145)$ dengan pengaruh tidak langsung melalui variabel intervening relasi guru-siswa sebesar 0,04.

Tabel 1. Signifikansi Koefisien Korelasi Ganda

\begin{tabular}{|c|c|c|}
\hline & Model \\
\hline & & 1 \\
\hline \multicolumn{2}{|l|}{$\mathrm{R}$} & .288 \\
\hline \multicolumn{2}{|c|}{ R Square } & .083 \\
\hline \multicolumn{2}{|c|}{ Adjusted R Square } & .69 \\
\hline \multicolumn{2}{|c|}{ Std. eror of the Estimate } & 3.793 \\
\hline & $\begin{array}{l}\mathrm{R} \text { Square } \\
\text { Change }\end{array}$ & .083 \\
\hline & F Change & 5.850 \\
\hline & df1 & 2 \\
\hline & df2 & 129 \\
\hline & $\begin{array}{l}\text { Sig. } \\
\text { Change }\end{array}$ & .004 \\
\hline
\end{tabular}

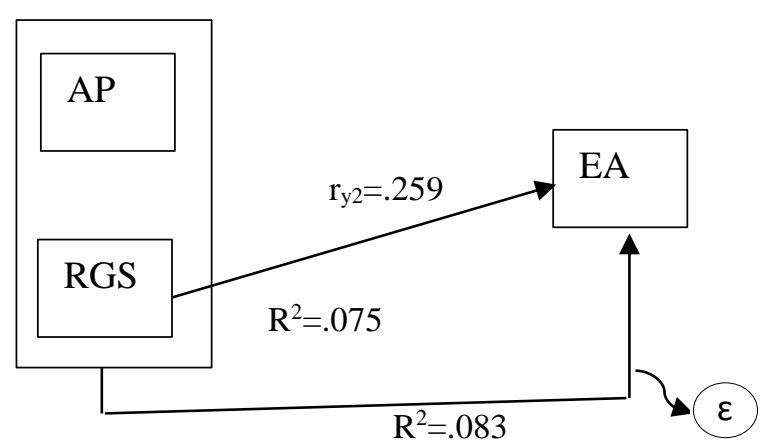

Gambar : Model hipotetik pengujian hipotesis

Identifikasi keberadaan pengaruh tidak langsung yang diperoleh lewat data empiris membentuk model hipotetik baru yang memosisikan relasi guru siswa sebagai mediator pengaruh academic press terhadap emotional adjustment

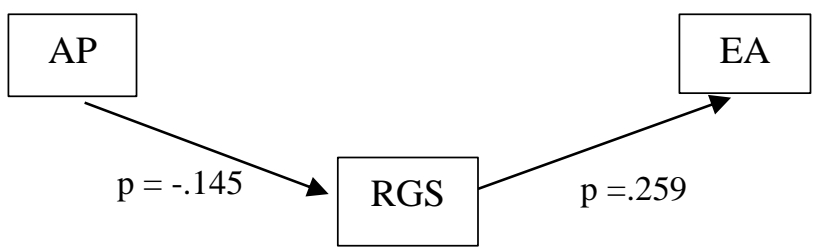

Gambar : Model hipotetik analisis jalur

Berdasarkan analisis yang dilakukan, usaha peningkatan prestasi akademik tidak berpengaruh negatif secara 
langsung pada emotional adjustment anak terhadap sekolah dan aktivitas bersekolah. Artinya semakin bertambah pemberian bentuk-bentuk normatif seperti pekerjaan rumah, jumlah kelas pengajaran, tantangan akademik dan standar spesifik pencapaian siswa serta program asesmen performa pencapaaian dan belajar (Lee et al., 1999) secara langsung tidak berpengaruh pada semakin rendahnya tingkat emotional adjustment anak pada sekolah.

Emotional adjustment anak terhadap sekolah terdiri dari dua bentuk presepsi, yakni rasa suka pada sekolah (school liking) dan penghindaran atau penolakan terhadap sekolah (school avoidance) (Honma and Uchiyama, 2014). Keberadaan pengaruh tidak langsung dari academic press dimediasi oleh relasi guru siswa, akan berpotensi meningkatkan rasa suka anak terhadap sekolah dan kegiatan bersekolah, tetapi dapat juga meningkatkan kadar penolakan anak pada sekolah. Temuan ini dapat menjelaskan temuan sebelumnya yang mengatakan bahwa sikap yang diperlihatkan anak pada sekolah berkorelasi dengan partisipasinya dikelas dan prestasi akademiknya (Ladd, Buhs and Seid, 2000). Pada anak, semakin rendah rasa sukanya terhadap sekolah, semakin rendah pula partisipasi atau keterlibatannya pada kegiatan sekolah. Oleh karena itu, bagi siswa emotional adjustment disebut sebagai bagian dari school engagement atas perannya dilingkungan sekolah (Smith, 2011).

Adapun kecilnya nilai koefisien determinasi (ditunjukkan oleh $\mathrm{R}$ Square) academic press pada emotional adjustment diduga berhubungan dengan jumlah tambahan tugas atau materi belajar yang lebih sedikit pada anak usia dini dibandingkan pada usia yang lebih dewasa. Pada siswa kelas tinggi, diketahui academic press berkaitan erat dengan kepemilikan chronic pain (Zhang et al., 2015) dan menjadi salah satu penyebab academic stress. Penelitian menyebut kemunculan stres ini berhubungan dengan banyaknya tugas, kompetisi, dan konflik dalam hubungan sosial (Fairbrother and Warn,
2003). Bahkan kemunculan stres ini dapat diprediksi, seperti ketika belajar untuk ujian, kompetisi kelas, dan saat mempelajari sejumlah besar konten dalam waktu singkat (Abouserie, 1994).

Penjelasan tentang perbedaan tingkat academic press pada anak usia rendah dengan usia lebih dewasa beserta dampak yang terjadi menunjukkan sifat pengaruh yang sama (negatif) yang disumbangkan pada emotional adjustment anak (pada data statistik ditunjukkan dengan pengujian sisi kiri daerah penolakan). Namun konsep emik ini perlu diuji terlebih dahulu dengan data empiris di Indonesia dengan pengaruh budaya yang berbeda dari negara barat atau asal konsep ini diuji.

Selanjutnya mengenai pengaruh positif yang disumbangkan oleh relasi gurusiswa pada emotional adjustment memiliki kesesuaian dengan penjelasan teoritis dan hasil penemuan terdahulu. Penelitian sebelumnya menjelaskan bahwa relasi yang positif membantu perpindahan siswa prasekolah ke jenjang pendidikan dasar dan meningkatkan kesehatan sosial-emosinya (Murray, Murray and Waas, 2008), mengurangi dampak konflik dengan teman sebaya (Troop-Gordon and Kuntz, 2013), dan membantu siswa lebih lebih aktif dalam kegiatan di kelas, serta sebaliknya, lebih banyak konflik dengan guru memicu penghindaran anak terhadap aktivitas sekolah dan cenderung membuatnya mudah tersinggung di kelas (Yang and Lamb, 2014).

Keadaaan ini dapat dijelaskan lewat konsep teori kelekatan yang dijelaskan Bowlby, bahwa seperti kelekatan anak pada ibu atau pengasuhnya, relasi guru-siswa pada dasarnya menyediakan nilai positif bagi siswa dengan memosisikan guru sebagai sumber keamanan untuk mengaktualisasikan diri lewat eksplorasi kelas dan pengembangan potensi. Namun relasi ini pada praktiknya akan berbeda bentuk sesuai dimensi relasi yang terdiri atas closeness, conflict, dan dependency.

Kelekatan yang dibangun anak dengan pengasuhnya berperan penting dalam penyesuaian diri anak sepanjang 
hidup, termasuk pada aspek sosial emosi (Groh et al., 2014). Sebagai contoh, kelekatan aman yang terbangun akan berpengaruh positif pada saat anak berada dalam kondisi terpuruk. Mekanisme seperti ini yang menjadi landasan pengkajian relasi yang dibangun anak dengan orang lain yang berkontribusi pada emotional adjustment anak sesuai konteks keberadaannya. Begitu pula, pola asuh orang tua (ibu) dapat berpengaruh pada kecerdasan sosial anak yang berguna dalam emotional adjustment di lingkungan (Robiyah, Ekasari and Witarsa, 2018). Oleh karena itu, temuan penelitian bahwa relasi guru-siswa berhubungan positif pada emotional adjustment sejalan dengan pendapat bahwa hubungan anak dengan orang dewasa berperan dalam pembentukan kompetensi sosial yang berguna bagi penyesuaian positif di kelas (Hamre \& Pianta, 2001).

Penjelasan lain dapat dianalisa dari perspektif guru. Apabila relasi guru-siswa diterjemahkan sebagai hubungan interpersonal dua arah atau bersifat bidirectional (Mccormick et al., 2014), relasi hangat yang kuat mendorong guru menghabiskan banyak waktu dan energi untuk mengupayakan keberhasilan anak (Prasanti and Fitriani, 2018), berbeda dengan tingginya konflik dalam relasi menjadikan guru hanya berfokus pada pengendalian perilaku anak (Hamre and Pianta, 2001). Oleh karenanya, pada anak yang berelasi hangat dengan guru, emotional adjustment anak didukung dengan pencapaian prestasi akademik.

Adapun simpulan ketiga, bahwa secara bersama-sama academic press dan relasi guru siswa berpengaruh positif terhadap emotional adjustment atau bermakna bahwa apabila kedua variabel bebas meningkat pada tingkat yang seimbang, maka terjadi peningkatan emotional adjustment anak pada kondisi seimbang pula. Hipotesis alternatif pada kondisi simultan ini diterima, namun karena tidak ada pengaruh negatif langsung dari academic press terhadap emotional adjustment seperti pada pembuktian hipotesis pertama, maka pengaruh yang muncul diidentifikasi sebagai pengaruh tidak langsung yang dimediasi oleh variabel relasi guru-siswa.

Hal yang menarik yakni data pengaruh tidak langsung ini mendukung bahwa upaya guru dalam meningkatkan prestasi akademik siswa lewat pengajaran dan disiplin kelas ternyata secara langsung berpengaruh negatif pada relasi guru siswa sebesar 14,5\%. Sedangkan, ketika dimediasi dengan relasi positif yang tinggi dengan guru, pengaruh bersifat positif sebesar $4 \%$. Perubahan pengaruh ini dapat dijelaskan bahwa cara mereduksi dampak negatif akibat academic press dapat dilakukan dengan adanya dukungan sosial dan positive reappraisal (Murphy and Archer, 1996) yang berasal dari tingginya relasi positif guru-siswa. Sehingga, dalam keadaan relasi positif yang tinggi, peran academic press yang diupayakan guru dipahami siswa sebagai cara guru meningkatkan prestasi siswa yang melahirkan prestasi akademik dan kesejahteraan emosi. Penemuan inilah yang dianggap berelasi dengan saran Shouse (Shouse, 1996) dalam penelitiannya, bahwa academic press menjadi komponen tambahan yang penting pada sekolahsekolah berbasis komunitas, di mana telah tercipta relasi yang kuat antara anak dengan komunitas yang selanjutnya dibutuhkan untuk meningkatkan prestasi akademik anak.

Perbedaannya, sekolah yang disoroti oleh Shouse adalah sekolah berbasis komunitas, sehingga perlu didorong peningkatan prestasi akademik siswanya dengan tambahan academic press. Sedangkan dalam sampel penelitian ini, sekolah yang diteliti berbasis negeri (public school) dan swasta (private school) yang terstandarisasi tinggi (akreditasi A), sehingga fokus analisis peneliti lebih berkait pada konteks emosi siswanya. Hal ini dapat menjadi diskusi lebih lanjut, bahwa pada sekolah berbasis nonkomunitas, academic press berpengaruh tidak langsung pada persepsi anak dalam memandang sekolah. Besaran pengaruh ini mungkin akan berbeda secara signifikan 
pada konteks sekolah yang lain, termasuk berbasis komunitas.

Adapun yang harus diperhatikan adalah konteks pengaruh yang ditemukan dalam penelitian ini. Pengaruh positif ini muncul dalam kondisi tertentu yang harus diciptakan sedemikian rupa agar memiliki pengaruh sama seperti yang didapatkan pada hasil penelitian, yakni kondisi di mana peringkat hubungan relasi guru-siswa harus lebih tinggi dibandingkan academic press atas emotional adjustment.

\section{SIMPULAN}

Kesimpulan dari penelitian ini adalah 1) academic press tidak berpengaruh negatif secara langsung terhadap emotional adjustment, 2) relasi guru-siswa secara langsung berpengaruh positif terhadap emotional adjustment, serta 3) secara simultan academic press dan relasi gurusiswa berpengaruh positif pada emotional adjustment yang kemudian menjembatani pengetahuan adanya hubungan tidak langsung academic press terhadap emotional adjustment melalui relasi guru sisiwa sebagai mediator.

Academic press dapat meningkatkan prestasi akademik serta emotional adjustment siswa terhadap sekolah apabila diimbangi dengan tingginya relasi hangat (positif) guru-siswa. Pada kondisi ini, academic press berfungsi sebagai tantangan yang menggerakkan siswa untuk berusaha lebih besar dalam performa dan hasil belajar sedangkan relasi hangat dengan guru berfungsi menyediakan dukungan emosi yang positif bagi siswa untuk mengusai sejumlah beban belajar dan eksplorasi pembelajaran di kelas.

\section{UCAPAN TERIMA KASIH}

Peneliti mengucapkan terima kasih kepada sekolah-sekolah di Jakarta Timur yang telah berpartisipasi dalam penelitian ini, serta kepada pembimbing dan validator penelitian atas masukan dan umpan balik yang diberikan.

\section{DAFTAR PUSTAKA}

Abouserie, R. (1994) 'Sources and Levels of Stress in Relation to Locus of Control and Self Esteem in University Students', 14(3), pp. 323-330. doi: $10.1080 / 0144341940140306$.

Arbeau, K. A., Coplan, R. J. and Weeks, M. (2010) 'Shyness, teacher-child relationships, and socio-emotional adjustment in grade 1', International Journal of Behavioral Development, 34(3), pp. 259-269. doi: $10.1177 / 0165025409350959$.

Awaliyah, G. (2018) Aduan kekerasan fisik di dunia pendidikan capai 72 persen, republica.co.id.

Damanik, C. (2018) Siswa SD dihukum guru menjilati WC gara-gara tak bawa tugas, kompas.com.

Deasyanti (2015) School satisfaction and children's positive school adjusment. Charles Darwin University.

Fairbrother, K. and Warn, J. (2003) 'Workplace dimensions, stress and job satisfaction', Journal of Managerial Pshychology, 18(1), pp. 8-21. doi: $10.1108 / 02683940310459565$.

Garmabrata, G. (2018) Guru pemberi hukuman jilat WC kepada siswanya dimutasi, liputan6.com.

Groh, A. M. et al. (2014) 'The significance of attachment security for children's social competence with peers: A meta-analytic study', Attachment and Human Development, 16(2), pp. 103-136. doi: 10.1080/14616734.2014.883636.

Hamre, B. . and Pianta, R. C. (2006) 'Student-Teacher Relationships', Children's needs III: Development, prevention, and intervention. Edited by B. B.B and M. K.M. United States: National Association of School Psychologists, pp. 59-71.

Hamre, B. K. et al. (2008) 'Teachers' perceptions of conflict with young students: Looking beyond problem 
behaviors', Social Development, 17(1), pp. 115-136. doi: 10.1111/j.1467-9507.2007.00418.x.

Hamre, B. K. and Pianta, R. C. (2001) 'Early teacher-child relationships and the trajectory of children's school outcomes through eighth grade', Child Development, 72(2), pp. 625-638.

Hemphill, C. (2006) In Kindergarten Playtime, a New Meaning for 'Play', The Newyork Times.

Honma, Y. and Uchiyama, I. (2014) 'Emotional Engagement and School Adjustment in Late Childhood: The Relationship between School Liking and School Belonging in Japan', Psychological Reports, 114(2), pp. 496-508. doi: 10.2466/21.10.PR0.114k19w7.

Honma, Y. and Uchiyama, I. (2016) 'The relationships between role-taking ability and school liking or school avoidance', Comprehensive Psychology, 5, pp. 1-11. doi: $10.1177 / 2165222816648079$.

Ireson, J. and Hallam, S. (2005) 'Pupils' liking for school: Ability grouping, self-concept and perceptions of teaching', British Journal of Educational Psychology, 75(2), pp. 297-311. doi: 10.1348/000709904X24762.

Kemendikbud (2017) Langkah Strategis Perbaikan Sekolah di Tahun Ajaran Baru, kemendikbud.go.id.

Ladd, G., Buhs, E. and Seid, M. (2000) 'Children's Initial Sentiments About Kindergarten: Is School Liking an Antecedent of Early Classroom Participation and Achievement?', Merril-Palmer Quartley, 46(2), pp. 255-279.

Lee, V. E. et al. (1999) Social support, academic press, and student achievement: A view from the middle grades in Chicago. Improving Chicago's Schools. A report of the Chicago Annenberg Research Project. Chicago: Concortium on Chicago School
Research.

Mccormick, M. P. et al. (2014) 'Journal of Educational Psychology Teacher Child Relationship Quality and Academic Achievement in Elementary School: Does Gender Matter? Teacher - Child Relationship Quality and Academic Achievement in Elementary School : Does Gender Matter?'

Murphy, M. C. and Archer, J. (1996) 'Stressors on the college campus: A comparison of 1985-1993', Journal of College Student Development, 37(1), pp. 20-28.

Murray, C., Murray, K. M. and Waas, G. A. (2008) 'Child and teacher reports of teacher-student relationships: Concordance of perspectives and associations with school adjustment in urban kindergarten classrooms', Journal of Applied Developmental Psychology, 29(1), pp. 49-61. doi: 10.1016/j.appdev.2007.10.006.

Nadlir, M. (2018) Awal 2018, Laporan ke KPAI Didominasi Kasus Kekerasan Guru ke Siswa, kompas.com.

Nicolopoulou, A. (2010) 'The alarming disappearance of play from early childhood education', Human Development, 53(1), pp. 1-4. doi: $10.1159 / 000268135$.

Pianta, R. C. (2001) 'Student-teacher relationship Scale (STRS): Professional manual'. Psychological Assessment Resources, pp. 1-58.

Prabu, P. S. (2015) 'A study on academic stress among higher secondary students', International Journal of Humanities and Social Science Invention, 4(10), pp. 63-68.

Prasanti, D. and Fitriani, D. R. (2018) 'Building Effective Communication Between Teachers and Early Children In PAUD Institutions', Jurnal Obsesi : Jurnal Pendidikan Anak Usia Dini, 2(2), pp. 259-266. doi: 10.31004/obsesi.v2i2.96.

Robiyah, R., Ekasari, D. and Witarsa, R. (2018) 'Pengaruh Pola Asuh Ibu terhadap Kecerdasan Sosial Anak 
Usia Dini di TK Kenanga Kabupaten Bandung Barat', Jurnal Obsesi: Jurnal Pendidikan Anak Usia Dini, 2(1), pp. 74-81.

Roorda, D. L. et al. (2011) 'The influence of affective teacher-student relationships on students' school engagement and achievement: A meta-analytic approach', Review of Educational Research, 81(4), pp. 493-529. doi: $10.3102 / 0034654311421793$.

Russell, J. L. (2011) 'From child's garden to academic press: The role of shifting institutional logics in redefining kindergarten education', American Educational Research Journal, 48(2), pp. 236-267. doi: 10.3102/0002831210372135.

Shouse, R. C. (1996) 'Academic press and sense of community: Conflict, congruence, and implications for student achievement', Social Psychology of Education, 1(1), pp. 47-68. doi: 10.1007/BF02333405.

Smith, J. (2011) Measuring school engagement: A longitudinal evaluation of the School Liking and Avoidance Questionnaire from kindergarten through sixth grade. Arizona State University.

Troop-Gordon, W. and Kuntz, K. J. (2013) 'The unique and interactive contributions of peer victimization and teacher-child relationships to children's school adjustment', Journal of Abnormal Child Psychology, 41(8), pp. 1191-1202. doi: 10.1007/s10802-013-9776-2.
UNESCO (2015) Early childhood care and education, United Nations Educations, Scientific and Cultural Organization.

UNESCO (2016) Global Citizens for Sustainable Development: A Guide for Teacher. France: United Nations Educational, Scientific and Cultural Organization.

United Nations (2015) 'The Millennium Development Goals Report', United Nations, p. 72. doi: 978-92-1101320-7.

Valiente, C., Lemery-Chalfant, K. and Castro, K. S. (2007) 'Children's effortful control and academic competence: Mediation through school liking', Merrill-Palmer Quarterly, 53(1), pp. 1-25.

Yang, P. J. and Lamb, M. E. (2014) 'Factors influencing classroom behavioral engagement during the first year at school', Applied Developmental Science, 18(4), pp. 189-200. doi: 10.1080/10888691.2014.924710.

Zhang, X. et al. (2016) 'The relationship among school safety, school liking, and students' self-esteem: Based on a multilevel mediation model', Journal of School Health, 86(3), pp. 164-172. doi: 10.1111/josh.12364.

Zhang, Y. et al. (2015) 'A cross sectional study between the prevalence of chronic pain and academic pressure in adolescents in China (Shanghai)', BMC Musculoskeletal Disorders. BMC Musculoskeletal Disorders, 16(219). doi: 10.1186/s12891-0150625-z. 